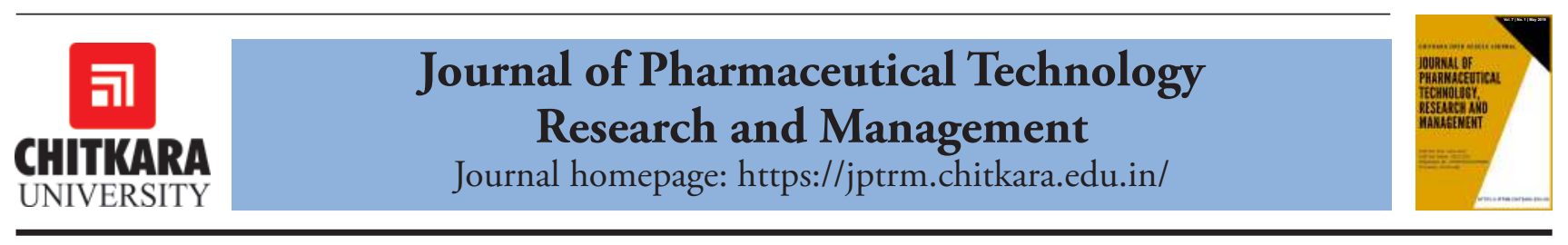

\title{
Cruz-Badiano Codex and the Importance of the Mexican Medicinal Plants
}

\author{
Chavarría $\mathrm{A}^{1^{*}}$ and Espinosa $\mathrm{G}^{1}$ \\ ${ }^{1}$ Instituto de Física, Circuito de la Investigación Científica Ciudad Universitaria CP 04510 Ciudad de México \\ *Email:acchs2002@yahoo.com.mx
}

ARTICLE INFORMATION

Received: Nov. 17, 2018

Revised: January 21, 2019

Accepted: Feb. 21, 2019

Published online: May 10, 2019

Keywords:

Martin de la Cruz; Juan Badiano; Mexica;

Traditional herbolary; Curative plants.

DOI: https://doi.org/10.15415/jptrm.2019.71003

\begin{abstract}
The plants have been used by human beings since thousands years ago as natural curative products. Ancestral populations from China, Egypt, India, and México, among others, were cultures that found the curative effects of different plants. A very invaluable document is the Cruz-Badiano codex. This codex was written in 1552 as a present to the King of Spain, the codex deals with herbolary and traditional Mexican medicinal plants. The main goal of this work is to show the importance of the Cruz-Badiano codex which is based on the native and traditional medicinal Mexican plants used to cure in the ancient times. A brief historical overview of the Cruz-Badiano codex, his origin and the round trip between México-Spain-México is described. Some of the beautiful handmade illustrations of Mexican medicinal plants are shown. And a brief review of plants that have been subject of pharmacological studies is given.
\end{abstract}

\section{Introduction}

The Mēxihcah (Mexica or Aztecs) used different herbs to treat many illnesses typical of México over hundreds of years. Later on, after the Spanish conquest of México in 1521, the information about these medicinal herbs that was transmitted by generations orally and was originally contained in pre-Columbian Aztec codices was transferred to other codices among which the Matritense, the Florentine and the Cruz-Badiano stand out [11].

Several native Mexican cultures were known for their extensive use of native herbs for medicinal purposes, by example the Mixtec and the Zapotec in the south, the Maya in the southeast of México, the Teotihuacan and the Purépecha in the center, and the Mexica across a large part of the country, used a wide variety of medicinal herbs years before the arrival of the Spanish conquerors, and continued using them years after the conquest. These herbs or medicinal plants were classified in different codices like the three mentioned above. Of these, the Cruz-Badiano codex, also known as Amate Cehuatl Xihuitl Pitli in Nahuatl, Libellus de Medicinalibus Indorum Herbis (Native medicines and herbs notebook) in Latin, or Codex Barberini and dating from 1552, is a pictorial compilation of medicinal plants and different remedies used by the natives to cure various physical ailments in New Spain in the XVI century, and is considered to be a master work of world medical literature [14] and according to Jesus Kumate [20] (former
Mexican Secretary of Health) is "the summary description of the medical practice of the Aztecs, not only for herbal medicine but also for its mineral, animal and psychological matter". Due to the importance of these plants, between 1550 and 1600, the basic chemical contents of these traditional medicinal herbs of Mexico were analyzed in Spain and other European countries, although their results were limited by the technology of the time and the little biological knowledge of the plants. Nowadays, thanks to new knowledge and technologies, different traditional medicinal plants have been studied with the aim of developing new drugs to treat various diseases and to benefit millions of people in the world.

The aim of the present work is to present the CruzBadiano codex that is based on the native and traditional use of medicinal Mexican plants. A brief historical overview of the Cruz-Badiano codex, his origin and the round trip between México-Spain-México. Additionally some handmade illustrations of Mexican traditional medicinal plants that are used till today are shown and a brief review of plants that have been subject of pharmacological studies is given.

\section{Material and Methods}

This work is a product of a bibliographical investigation where books, specialized articles and databases were 
consulted. Documentary information, the term codex (lat. codex) applies to ancient manuscripts prior to the origin of the printing. The Cruz-Badiano codex was written 31 years after the fall of Tenochtitlán, ancient capital of the Aztec Empire, by the native Martín de la Cruz and translated into Latin by the indigenous Juan Badiano in 1552 in El Colegio de la Santa Cruz (The College of the Holy Cross) in Tlatelolco, being the first book of medicine written in America [9]. The codex was commissioned and transported to Spain by Don Francisco de Mendoza, son of the first viceroy of New Spain, Don Antonio de Mendoza, as a gift to the King of Spain Carlos $\mathrm{V}[8,14]$, with the intention of obtaining permission from the Spanish Crown to trade with spices and medicinal plants of America [2].

There is little knowledge about the lives of the authors before and after the writing of the codex, but it is known that both belonged to El Colegio de la Santa Cruz. Martín de la Cruz was born in Tlatelolco, herbolary man, member of the indigenous nobility, healer of the viceroy Don Antonio de Mendoza and the native student's children of that college. Juan Badiano was born in of Xochimilco and was teacher of the El Colegio de la Santa Cruz. For the authors the preparation of the codex represented the opportunity to recommend the college to the King of Spain, in order to avoid its closure and obtain financial support for the same [28].

Cruz-Badiano codex description, the codex book front and back cover are in red velvet; the paper for the 140 pages used for the text and illustrations came from Genoa Italy. The writing of the texts was done by hand, and two types of ink were used: brown for all the texts, descriptions and remedies; and red for the names of the plants and the chapters of the manuscript. The red color, originally from México, came from the cochineal Dactylopius coccus that parasitizes plants of the genus Opuntia. The 185 handmade color illustrations were done by Mexican native artisans called Tlacuilos (the one who write or paint; painters of the codices, maps and murals) in Nauahtl $(17,27)$.

One of the most notable features of the codex are the 185 paintings of the plants that illustrate it, some of which are complemented by images of animals, rocks and water bodies. The latter not only serve as decorative elements, in some painting they are indicators of environmental and ecological characteristics of the place where the plants grow [25], by example, figure I illustrates the plant Nonochton azcapan ixhua (unidentified species) growing close to the ants. These images capture the natives pictorial tradition and mix it with the concept of western art, with which the codex represents the union of indigenous art, ideography and symbolism with European science, giving the codex an aesthetic and scientific value [13].

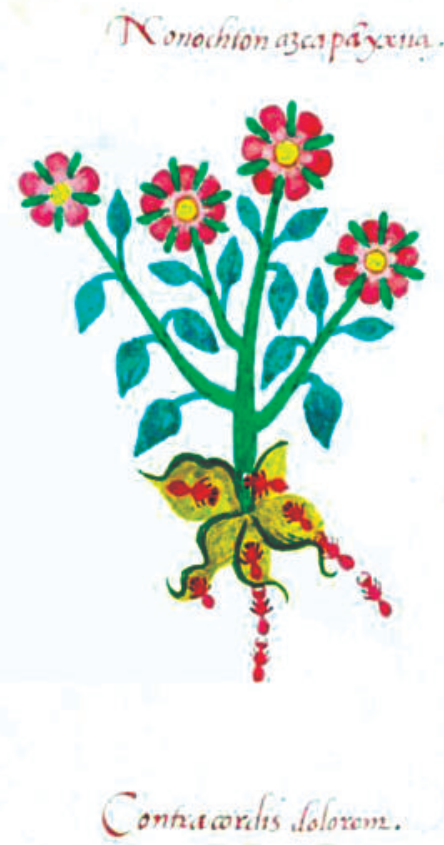

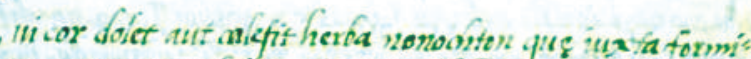

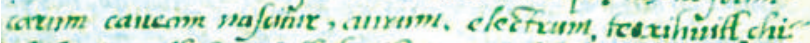

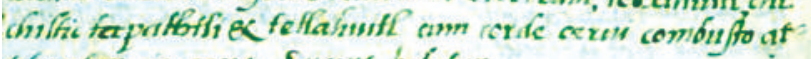
forcnfier m aqua. Succus hibefin.

Figure 1. Plant Nonochton azcapan ixhua (unidentified species) growing close to the ants and their use (Latin text). Source CruzBadiano codex.

Codex structure, the codex has 13 chapters where the remedies for the treatment of different diseases, infections and wounds are described. The first seven chapters mention the cures for specific parts of the body such as head, which includes: hair, eyes, ears, nose, mouth (and its internal structures), face, throat and neck; parts of the thorax like: chest, heart and abdomen; and the upper extremities [8]. In chapters eight, nine and ten, the cures for the pubis area of the human body, urinary diseases, armpits odor, feet problems and joint problems are mentioned; also include the treatment for: the fatigue, body burns, struck by lightning, against fear, hit by the gale, among others [8].

Chapter eleven is dedicated to treat women period problems, childbirth and breastfeeding. Chapter twelve is devoted to the treatment of burns in children, and for infants who don't want breast milk. And chapter thirteen focuses on signs of the proximity of death, and some remedies for the dying $[8,28]$.

The diseases and treatments described in the codex are arranged following a sequence that starts in the head and ends in the feet [24]. This classification is in accordance with 
the native vision of the correspondences to the 13 heavens and the nine regions of the underworld, ruled by the forces and beings that reside in each one [28]. Another very interesting and important classification in the Cruz-Badiano codex is the cold and hot nature of the different parts of the human body, related to the cosmic equivalences. The entire human body can be characterized by the temperature and together all the parts must be in balance for the proper functioning of the organism [28].

Journey to Spain and return to México, after his arrival in Spain, the codex was presented to the future King of Spain Felipe II (son of King Charles V), who ordered it to be archived in the Royal Library in 1553 [28]. In the beginning of the XVII century the codex passed into the custody of Diego Cortavila y Sanabria, apothecary of King Felipe IV. Later, around 1625, the codex was obtained by Cardinal Francisco Barberini, nephew of Pope Urban VII, and was included in the Barberini library for the next three centuries. In 1902 this library was acquired by the Vatican [14, 20], and in 1929 the codex is discovered by Charles Upson Clark, professor of history at Columbia University. Ten years later was published in english by William Gates, and also in the same year, in spanish by Demetrio S. García [14]. In the year 1990 the Cruz-Badiano codex returns to México as a gift from Pope John Paul II to the Mexican, and since then it is under the safekeeping in the library of the Instituto Nacional de Antropologia e Historia (INAH). Finally, thanks to scanning technologies, the codex was totally digitized and the entire images are available on the INAH website (INAH).

Mexican medicinal plants today, the botanical diversity in México is the result of the physical complexity of the territory (territorial extension, diversity of climates, altitude, topography, geographic location, geology, etc.) [10]. The country has 23, 314 species of vascular plants [29], many of which have been used in ornamental, food and medicinal aspects. Many of the pre-Hispanic medicinal plants are in current use till this days, such as the chicalote (Argemone ochroleuca Sweet) which is used to treat eye conditions, and the pericon (Tagetes lucida Cav.) that is used to treat digestive disorders (Biblioteca Digital Medicina Tradicional Mexicana) [15].

Some examples of the plants mentioned in the codex are shown on figures 2 to 7 ; these plants are sold commercially and are still used, although the currently use is not always related to its original use.

Quauhtlaxoxocoyolin (Begonia gracilis Kunth) (figure II). The Cruz-Badiano codex (XVI century) indicates that the juice of this plant was used for the treatment of baldness and dandruff [8] (INAH). Currently is used as a purgative (Biblioteca Digital Medicina Tradicional Mexicana).
Xaltomatl (Jaltomata procumbens (Cav.) J.L. Gentry) (figure III). The Cruz-Badiano codex indicates that when the eyes are warmed by an illness, they are treated with a distillate of the root of this plant [8] (INAH). Currently it is used to treat ulcers, bile, nerves, and diarrhea, among others (Biblioteca Digital Medicina Tradicional Mexicana).

Azcapan yxhua tlahcolpahtli (Datura stramonium L.) (figure IV). This plant, which is born next to the anthills, was used to reconcile or attract sleep [8] (INAH). In different states of the country is currently used for its analgesic qualities, as an anti-inflammatory of the womb, to treat vaginal infections, to lessen the pain of childbirth, in skin problems, among many others (Biblioteca Digital Medicina Tradicional Mexicana).

Tememetla (Echeveria gibbiflora DC.) (figure V). In the XVI century, the leaves of this herb, ground in water and mixed with other plants and white soil, were used as part of the treatment to cure the inflamed mouth [8] (INAH). Currently, it continues to be used to cure oral ailments, in addition to dermatological treatments (Biblioteca Digital Medicina Tradicional Mexicana).

Tlalhaueuetl (Agastache mexicana (Kunth) Lint \& Epling) (figure VI). The root of this plant was used to treat wounds [8] (INAH). Currently has a variety of uses: to treat scares and nerves, in treatments related to gastric problems, cardiovascular disorders, and when mixed with other plants are used to treat different diseases (Biblioteca Digital Medicina Tradicional Mexicana).

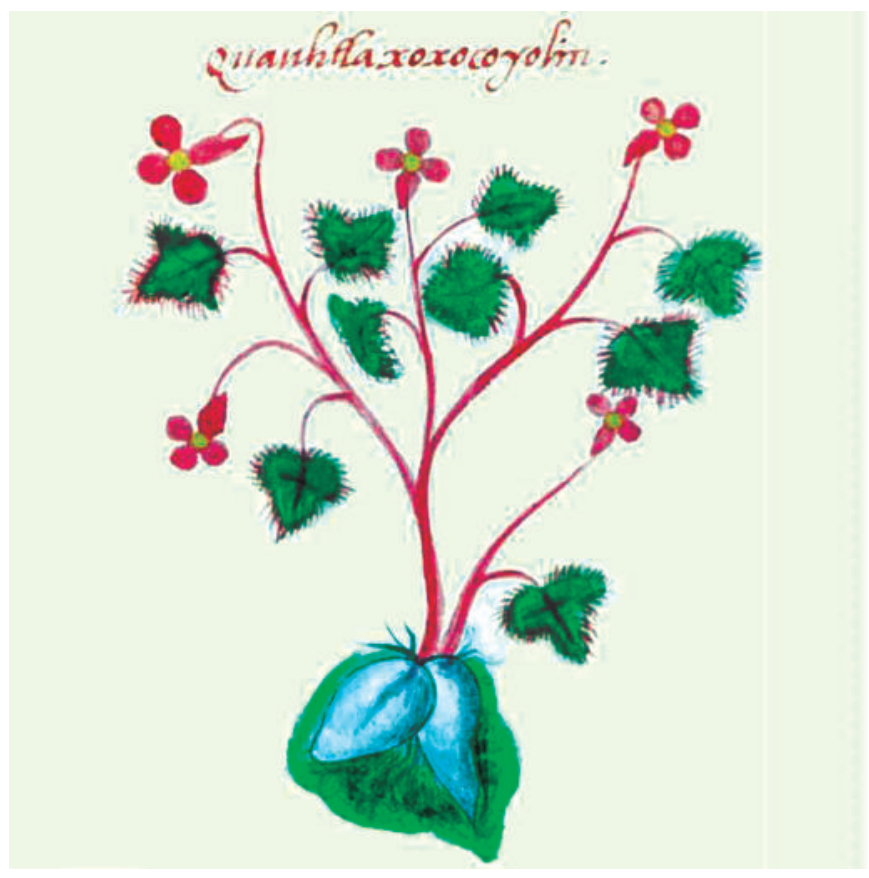

Figure 2. Plant Quauhtlaxoxocoyolin (Begonia gracilis Kunth). Source Cruz-Badiano codex. 


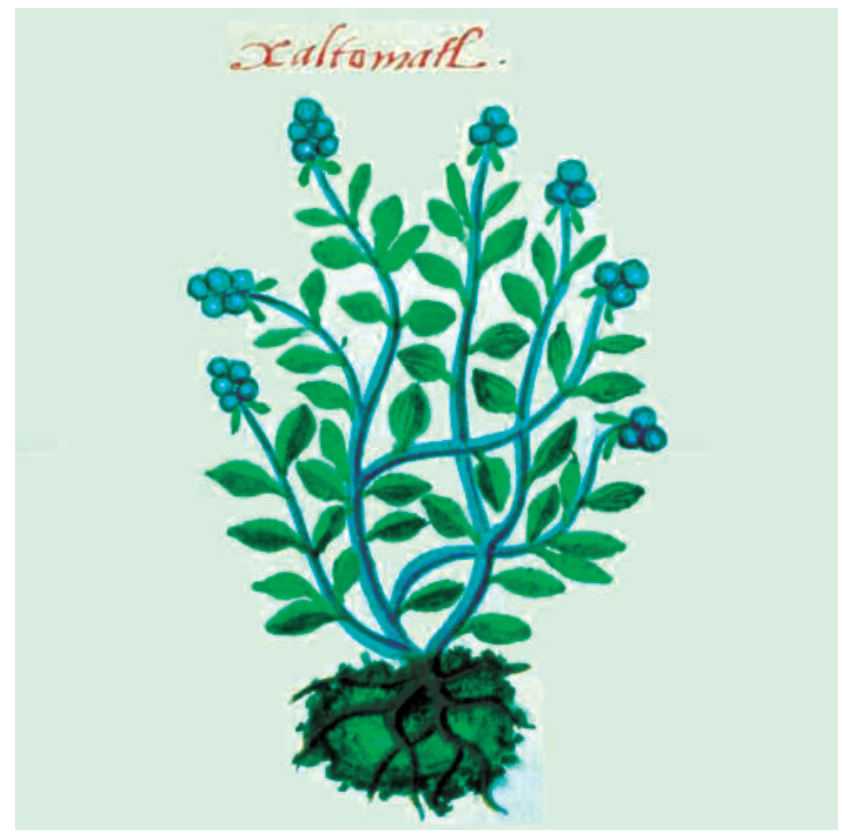

Figure 3. Plant Xaltomatl (Jaltomata procumbens (Cav.) J.L.Gentry). Source Cruz-Badiano codex.

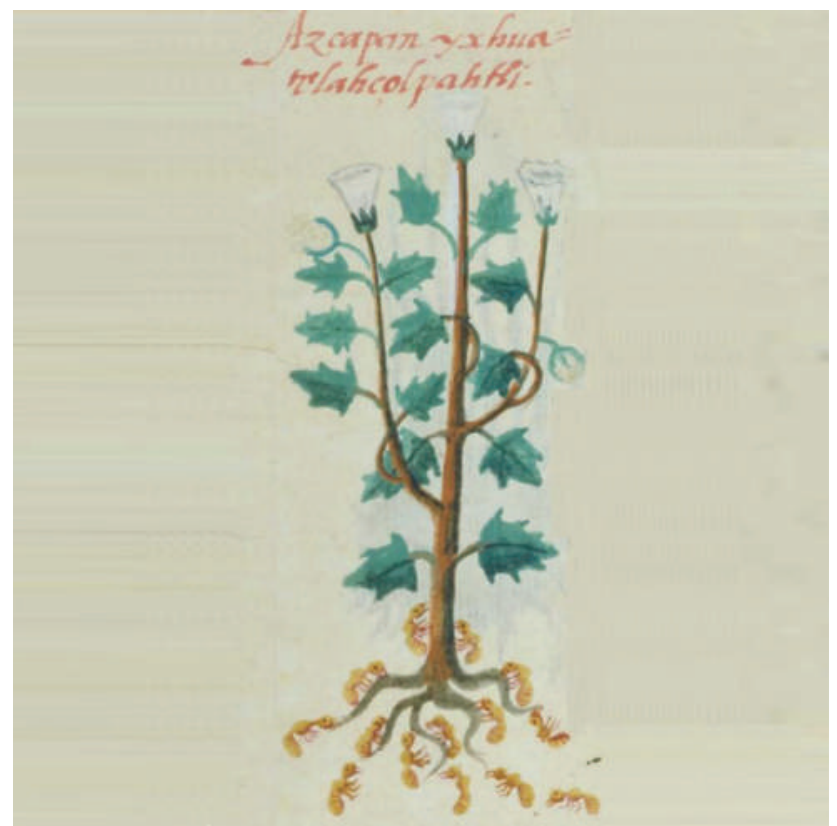

Figure 4. Plant Azcapan yxhua tlahcolpahtli (Datura stramonium L.). Source Cruz-Badiano codex.

Yolloxochitl (Talauma mexicana (DC.) G. Don.) (figure VII). In the codex Martín de la Cruz notes that as part of the treatment for mental stupor the person, before eating, should drink the juice of flowers and ingest the bark and roots of this plant [8] (INAH). It is currently used for heart conditions, and when mixed with other plants are used to treat different diseases (Biblioteca Digital Medicina Tradicional Mexicana).

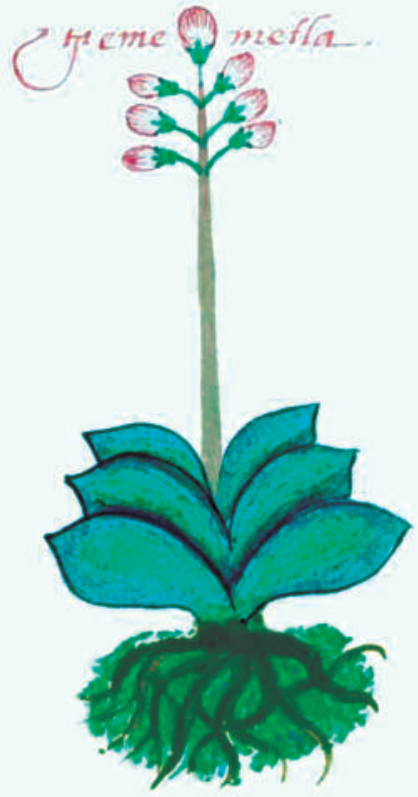

Figure 5. Plant Tememetla (Echeveria gibbiflora DC.). Source CruzBadiano codex.

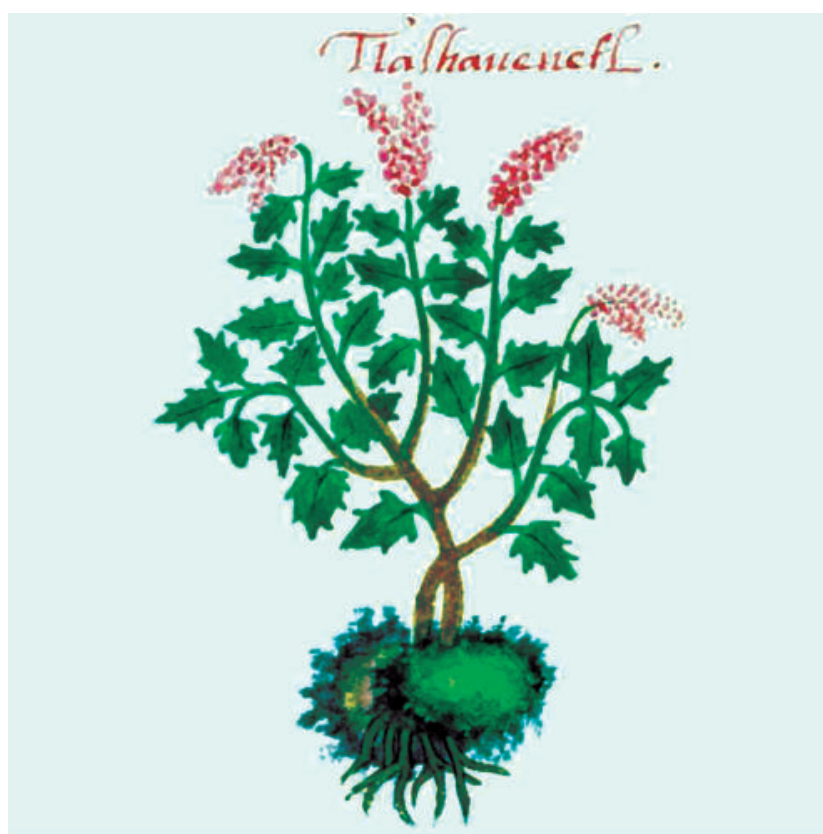

Figure 6. Plant Tlalhaueuetl (Agastache mexicana (Kunth) Lint \& Epling). Source Cruz-Badiano codex.

Several of the codex plants, whose biological identification is currently known, have been the subject of pharmacological studies to identify the chemical compounds they possess and the real effect they generate. An example of the above is the work carried out by [12], who found that low concentrations (from 0.1 to $10.0 \mathrm{mg} / \mathrm{kg}$ ) of aqueous extracts of Agastache 
mexicana ssp. mexicana and ssp. xolocotziana have an inhibitory activity of anxiety, while high concentrations (over $100 \mathrm{mg} / \mathrm{kg}$ ) induce a sedative action that affects general activity and motor action. In addition they found that these A. mexicana subspecies don't have a significant health risk because of their low toxicity. In these work the authors used a high performance liquid chromatography-electro spray ions-mass spectrometry (HPLC-ESI-MS) method to determine and compare the chemical composition of both $A$. mexicana subspecies, and found: Luteolin7-O- $\beta-$ D-glucoside, Luteolin7-O- $\beta-\mathrm{D}-\left(6^{\prime \prime}-\mathrm{O}\right.$-malonyl)-glucoside, Diosmetin 7- $\beta$-O-glucoside, Diosmetin 7-O- $\beta$-D- $\left(6^{\prime \prime}-\mathrm{O}-\right.$ malonyl)-glucoside, Acacetin, 7-O- $\beta$-glucoside, Acacetin 7-O- $\beta$-D-(6"-O-malonyl)-glucoside, Acacetin-7-O- $\beta$ glucoside-D-(2"-acethyl-6"malonyl), Acacetin, Diosmetin, GardeninApNa, 5,6,7,8,3-Pentahydroxy,4-methoxyflavone and 8-Hydroxy-salvigenin.

In another work, [19] studied Agastache mexicana ssp. xolocotziana essential oil extract to evaluate their antifungal activity efficacy as a substitute for synthetic chemical fungicides. Using Hydro-distillation and GC-MS they extracted and identify the components of the oil and found that estragole and methyl eugenol were the major components. This essential oil shows a strong antifungal activity against a panel of eleven fungal strains isolated from wheat grains during storage. The minimal inhibitory concentration determined for all the strains tested range from 0.3 to $30 \mu \mathrm{g} / \mathrm{mL}$ and show no toxicity when exposed to neither human-derived macrophages nor brine shrimp.

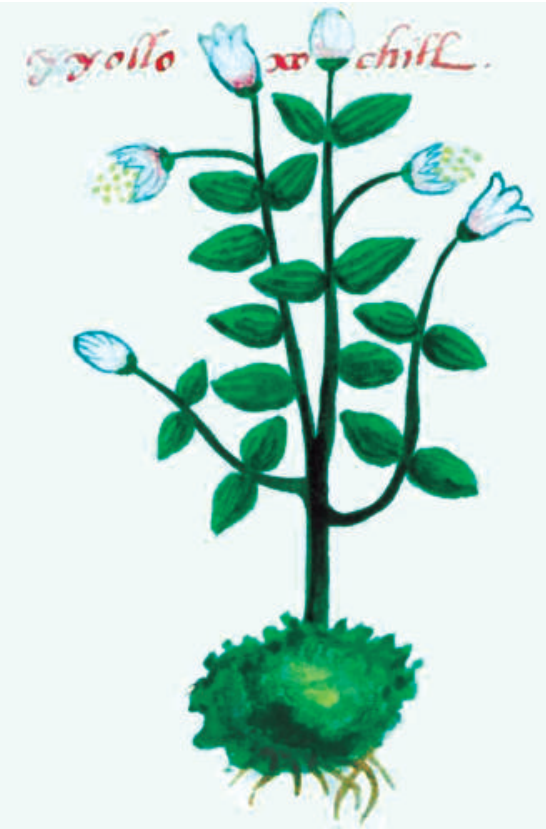

Figure 7. Plant Yolloxochitl (Talauma mexicana (DC.) G. Don.). Source Cruz-Badiano codex.
In the search for novel molecules with therapeutic properties for treating asthma, especially those which involve a contractile process of the smooth muscle cells, the Mexican medicinal plants Agastache mexicana and Talauma mexicana organic extracts were evaluated exvitro to determine their relaxing activity on the contractions induced by carbachol in isolated rat tracheal rings. Extracts were obtained by maceration at room temperature using hexane, dichloromethane and methanol for each plant material, and the results revealed that the extracts with more significant effects were dichloromethanic extracts of $T$. mexicana, while the extracts obtained from $A$. mexicana were fully effective but less potent than T. mexicana $[23,22]$ used the purified fraction from the plant from the Crassulaceae family named Echeveria gibbiflora, which is popularly used as a vaginal postcoital rinse to prevent pregnancy without side effects, to evaluate whether the effect on the modification of human sperm plasma membrane and metabolism is adequate for a male contraception. The results shows an enhanced activity of the immobilizing and agglutination effects was induced instantaneously after the addition the purified fraction of E. gibbliflora in sperm, also the hypotonic-like effect included a distension of the plasma membrane over the acrosome region and in some occasions around the sperm middle piece. In a similar work [6] employed the aqueous crude extract of $E$. gibbliflora to evaluate the functional parameters of mouse sperm, to evaluated its effect on $\mathrm{Ca}^{2+}$ influx and to determine the acute toxicity and they found that the capacitation and acrosome reaction suffered a significant decrease in a concentration-dependent manner, coinciding with the reduction of $\mathrm{Ca}^{2+}$ influx, however, the sperm viability was not affected by the presence of different concentrations of the aqueous crude extract. Finally the aqueous crude extract show an LD50 of $3,784.42 \mathrm{mg} / \mathrm{kg}$ and can be classified as a low toxic substance.

Montanoa tomentosa, known as zoapatle in México is a plant that has been used in traditional medicine for the last five hundred years and is appreciated for its medicinal properties. Its phytochemical studies have revealed that contains several classes of chemical constituents including flavonoids and terpenoids, and is well recognized that many of these compounds produce anxiolytic-like effects. [26] tested the anxiolytic-like effect at different concentrations $(1.5,3.0,6.0$ and $12.0 \mathrm{mg} / \mathrm{kg})$ of $M$. tomentosa in male Wistar rats and they found that at $3.0 \mathrm{mg} / \mathrm{kg}$ the anxiolyticlike effects is induced without producing locomotor impairments; however, at higher doses sedative effects were observed. Another compounds obtained from the leaves of $M$. tomentosa are the diterpenoid oxepanes zoapatanol, montanol, tomentanol and tomentol, which have been using for hundred years to prepare tea to induce menses, labor, and terminate early pregnancy [7]. 
Another contribution of the Cruz-Badiano codex, is the first illustration and record of the Tlilxochitl (Black Flower), now known as vanilla (Vanilla planifolia Andrews) [16]. This species of orchid is a very important Mexican present to the world, first was taken to Europe by Spaniards, and currently is known all over the world. Is one of the most popular spices and is found in the third place after saffron and cardamom as flavorings [3]. Currently the vanilla it has been used: a) in medicine, their extracts are used in aromatherapy, to diagnose Alzheimer, as cancer inhibitor; b) in pharmacy, to mask unpleasant taste medicines, especially for children; c) as antioxidant, the vanillin has antioxidant capacity, also is used in the food area as preservative; d) as antimicrobial, the vanilla properties can inhibit the growth of Escherichia coli, Lactobacillus plantarum, and Listeria innocua; e) in perfume industry, because its aromatic characteristics, vanilla was added to products for beauty care such as soaps, shower gels, among others and $f$ ) in foods and drinks [3].

In a different kind of study, [11] determined by gamma spectrometry the natural and artificial radioactivity concentration in 30 Mexican medicinal plants and found different contents of natural $40 \mathrm{~K}$ and low concentration levels of natural radioactivity and no artificial radionuclides. A few of the analyzed plants are known since the times of the codex, like Agastache mexicana, Datura stramonium, Talauma mexicana, Selaginella lepidophylla and Montanoa tomentosa. In this work the radiological content of the plants analyzed does not represent a risk to the health of the consumers.

Economic importance of the Mexican medicinal plants, in México, around 3,352 species of plants are used to treat illnesses [5] of the nervous, vascular, respiratory, digestive, urinary, reproductive system, among others. Due to its low cost and easy access, many doctors and health specialists in México prescribe various medicinal plants, ingested mainly in the form of infusion, for the treatment of not very severe diseases of the respiratory and digestive system [1]. Around de $90 \%$ of the Mexican population consumes traditional herbs, for $45 \%$ of the country's population (in part because their economic situation) it is the only medicinal resource they can have access to, while the other $45 \%$ uses medicinal plants in combination with allopathic medicines [21]. Just in México City around nine tons of medicinal plants are sold in a single day in different markets, and up to ten tons can be sold in the most well-known market in the city (Sonora Market) [21]. The market for medicinal plants is thus surprisingly large and very important economic spill in the country. From a socioeconomically point of view the Mexican herb industry gives employment to several thousand families, both urban and rural area.

Final comment, the Cruz-Badiano codex is a compendium of the remedies used by the natives to cure various ailments and is the result of the knowledge generated by the interaction of the natives with their environment and their religious beliefs. Its elaboration was possible thanks to the interest of Spaniards who sought to obtain benefits from the medicinal plants of the new world, and a group of natives who wished to save the El Colegio de la Santa Cruz; and unlike the Mayan culture, whose codices were destroyed on July 12 in 1562 by Diego de Landa Calderon, the knowledge embodied in the Cruz-Badiano codex opens a window to the culture and traditional medicine of the Mexicas. In recent year several plants mentioned in the codex have been the subject of pharmacological studies with the aim of obtaining new drugs for medicine.

\section{Conclusion}

The Cruz-Badiano codex is an invaluable historic document, with beautiful handmade illustrations. It is the first written record of the use of several Mexican medicinal plants. Many medicinal herbs mentioned in the codex are used in the 21st century to treat different diseases. Several pharmacological studies have shown the effect of the different chemical compounds of many plants of the codex.

\section{Acknowledgments}

The authors wish to thanks to Master of Science Abigail Contreras, Carlos Zapata and Jose Ignacio Golzarri for their technical help, and to medical doctor Aaron Espinosa Atri for his useful comments. To the Instituto Nacional de Antropologia e Historia (INAH) for the codex images. This work was partially supported by UNAM-DGAPA-PAPIIT Project IN102819.

\section{References}

[1] Alonso, A. J. Domínguez, F. Maldonado, J. J. Castillo, L. J. Carranza-Álvarez, C. Solano, E. et al., (2017). Use of medicinal plants by health professionals in México. J Ethnopharmacology 198, 81-86. http://dx.doi.org/10.1016/j.jep.2016.12.038

[2] Aranda, A. Viesca, C. Sánchez, G. Sánchez, G. Ramos de Viesca, M. Sanfilippo J. (2003). La materia medica en el Libellus de Medicinalibus Indorum Herbis. Revista de la Facultad de Medicina UNAM 46(1), 12-17.

[3] Baqueiro, I. Guerrero, J. (2017). Vanilla (Vanilla planifolia Andr.), its residues and other industrial byproducts for recovering high value flavor molecules: A review. J Appl Res Med Aromat Plants 6, 1-9. http://dx.doi.org/10.1016/j.jarmap.2016.10.003 
[4] Biblioteca Digital Medicina Tradicional Mexicana. (2009). Universidad Nacional Autónoma de México. www.medicinatradicionalmexicana.unam.mx/ index.php (Accessed 6 December 2017).

[5] Bye, R. (1998). The role of humans in the diversification of plants in México. In: Diversidad Biológica de México: Orígenes y Distribución. Instituto de Biología, Universidad Nacional Autónoma de México. México.

[6] Cordero, J. Aguirre, Ch. Guzmán, J. G. Sánchez, C. E. Flores, J. C. Rodríguez, L. (2016). Effects of aqueous crude extract of Echeveria gibbiflora on mouse sperm function. Syst Biol Reprod Med 62(5), 343-352. https://doi.org/10.1080/19396368.2016.1203044

[7] Cossy, J. Bellosta, V. Taillier, C. (2008). Chapter 3. Total syntheses of zoapatanol. In: Strategies and Tactics in Organic Synthesis vol. 7. Elsevier.

[8] De la Cruz, M. (1552). Libellus de Medicinalibus Indorum Herbis. Manuscrito Azteca de 1552. Versión española con estudios y comentarios por diversos autores. Instituto Mexicano del Seguro Social. México.

[9] Del Pozo, E. C. (1964). Prefacio. In: Libellus de Medicinalibus Indorum Herbis. Instituto Mexicano del Seguro Social. México.

[10] Durand, L. Neyra, L. (2010). La diversidad biológica de México: Ecosistemas, Especies y Genes. In: La Biodiversidad de México. Inventarios, manejos, usos, informática, conservación e importancia cultural. Fondo de Cultura Económica. México.

[11] Espinosa, G. Golzarri, J. I. Navarrete, J. M. (2016). Determination of the natural and artificial radioactivity of a selection of traditional Mexican medicinal herbs by gamma spectrometry. J Radioanal Nucl Chem 307(3). 1717-1721. https://doi.org/10.1007/s10967-015-4485-7

[12] Estrada, R. López, C. Ferreyra, O. A. Dorantes, A. M. Heinze, G. Moreno, J. et al. (2014). Central nervous system effects and chemical composition of two subspecies of Agastache mexicana; an ethnomedicine of México. J Ethnopharmacol 153(1), 98-110. http://dx.doi.org/10.1016/j.jep.2013.12.057

[13] Fernández, J. (1964). Estudios y Comentarios. Capitulo II. Las miniaturas que ilustran el Códice. In: Libellus de Medicinalibus Indorum Herbis. Instituto Mexicano del Seguro Social, México.

[14] García, C. J. Blanco, F. (2004). La cirugía plástica y el Códice De La Cruz-Badiano. Medicina Universitaria 6(22), 51-54.

[15] García, F. López, M. Rodríguez, S. Aguilar, A. (2012). Etnobotánica y morfo-anatomía comparada de tres especies de Tagetes que se utilizan en Nicolás Romero,
Estado de México. Bot Sci 90(3), 221-232. http:// www.scielo.org.mx/scielo.php?script $=$ sci_arttex t\&pid=S2007-42982012000300001 (Accessed 22 January 2018).

[16] Gómez, L. (2008). Vanilla planifolia, the first Mesoamerican orchid illustrated, and notes on the de la Cruz-Badiano codex. Lankesteriana 8(3), 81-88. http://dx.doi.org/10.15517/lank.v8i3.18321

[17] González, L. (2015). Los tlacuilos y la construcción del espacio novohispano en el siglo XV. Revista Digital Universitaria 16(4). http:/www.revista.unam.mx/ vol.16/num4/art29/index.html (Accessed 15 January 2018).

[18] Instituto Nacional de Antropología e Historia (INAH). Available at: http://www.codices.inah.gob.mx/pc/ contenido.php?id=12 (Accessed 15 January 2018).

[19] Juárez, Z. N. Hernández L. R. Bach, H. SánchezArreola, E. Bach, H. (2015). Antifungal activity of essential oils extracted from Agastache mexicana ssp. xolocotziana and Porophyllum linaria against postharvest pathogens. Ind Crops Prod 74(15), 178-182. http://dx.doi.org/10.1016/j.indcrop.2015.04.058

[20] Kumate, J. (1992). Presentación. In: Estudios actuales sobre el Libellus de Medicinalibus Indorum Herbis. Secretaria de Salud, México.

[21] Muñeton, P. (2009). Plantas Medicinales: Un complemento para la salud de los mexicanos. Revista Digital Universitaria 10(9). http://www.revista. unam.mx/vol.10/num9/art58/int58.htm (Accessed 6 December 2017).

[22] Reyes, R. Merchant, H. Ortega, A. Delgado, N. M. (2002). Male contraception, IV: Hypotonic-like effect from Echeveria gibbiflora on human sperm. Arch Androl 48(6), 443-449. http://dx.doi.org/10.1080/01485010290099327

[23] Sánchez, A. Mantecón, P. Castillo, P. Villalobos, R. Ibarra, M. Estrada, S. (2014). Tracheal relaxation of five medicinal plants used in México for the treatment of several diseases. Asian Pacific J Trop Med 7(3), 179-183. https://doi.org/10.1016/S1995-7645(14)60017-1

[24] Sanfilippo, J. (1992). La materia médica europea en el Libellus: Agua, sal y sustancias orgánicas. In: Estudios actuales sobre el Libellus de Medicinalibus Indorum Herbis. Secretaria de Salud, México.

[25] Somolinos, G. (1964). Estudios y Comentarios. Capítulo VI. Estudio Histórico. In: Libellus de Medicinalibus Indorum Herbis. Instituto Mexicano del Seguro Social, México.

[26] Sollozo, I. Estrada, E. Carro, M. López, C. (2015). $\mathrm{GABA}_{\mathrm{A}} /$ benzodiazepine receptor complex mediates 
the anxiolytic-like effect of Montanoa tomentosa. J Ethnopharmacology 162(13), 278-286. http://dx.doi.org/10.1016/j.jep.2014.12.070

[27] Stols, A. (1964). Estudios y Comentarios. Capitulo I. Descripción del Códice. In: Libellus de Medicinalibus Indorum Herbis. Instituto Mexicano del Seguro Social, México.
[28] Viesca, C. (1992). El Libellus y su contexto histórico. In: Estudios actuales sobre el Libellus de Medicinalibus Indorum Herbis. Secretaria de Salud, México.

[29] Villaseñor, J. L. (2016). Checklist of the native vascular plants of México. Rev Mex Biodivers 87(3), 559-902. http://dx.doi.org/10.1016/j.rmb.2016.06.017 